\title{
Genetic and Non-genetic Factors Affecting some Productive and Reproductive Traits in Holstein-Friesian Dairy Cows Raised in Egypt for the First Two Lactations
}

\author{
Osman M. M., Khairy M. El-Bayomi ${ }^{1}$ and Sherif A. Moawed
}

Department of Animal wealth Development, Faculty of Veterinary Medicine, Suez Canal University, Ismailia, Egypt. ${ }^{1}$ Department of Animal Wealth Development, Faculty of Veterinary Medicine, Zagazig University, Zagazig.

\begin{abstract}
The present study was conducted to investigate the effects of some non-genetic factors as year and season of calving on productive and reproductive traits of dairy Holstein-Friesian cows together with the effect of genetic variation in the form of sire analysis on these traits. A total of 3460 lactation records were used for 1059 dairy cows that represented the period from 1998 to 2010. Studied traits were total milk yield (TMY), days in milk (DIM), fat yield (FY), protein yield (PY), dry period (DP), age at first calving (AFC), number of services per conception (NSC), days open (DO) and calving interval (CI). Analysis was done using sire model by Harvey (1990) software for the first and second lactations. The present herd showed high milk production around $8750 \mathrm{~kg}$ per lactation period. Sire effects were significant $(\mathrm{P} \leq 0.05)$ on all traits. Year and season of calving had significant effects on most of studied traits. Linear and quadratic regression coefficients of age at first calving, days open and total milk yield were significant for most of traits. Balanced and unbiased estimates for genetic evaluation could be obtained if the environmental factors fitted in the statistical models.
\end{abstract}

Keywords: Milk produccion, Dairy cattle, Productive and reproductive traits, sire model

\section{INTRODUCTION}

Milk production performance of Holstein-Friesian dairy cattle depends on genetic and environmental factors. Genetic background, climate, diseases, feeding, year and season of calving have been reported to affect milk production in tropics (Msanga et al, 2000 and Epaphras et al, 2004). Breed, age, stage of lactation and parity also influence milk production. Another important cause of variation of milk production is the effect of sires that have been used in selection programs (Das et 
al, 1999; Galina et al, 2001 ad Combellas et al, 2003).

Holstein-Friesian cattle breed in Egypt is considered as the best cattle breed for milk production in tropical conditions. Environmental factors such as year and season of calving and age affect its productivity and there is a need to delineate them for unbiased genetic evaluation. The objective of the present study is to investigate the effects of some environmental (non-genetic) factors including year and season of calving together with sire effect on some productive and reproductive traits in a population of Holstein-Friesian dairy cows in Egypt.

\section{MATERIAL AND METHODS}

Data collection:

Data of the present study were collected from a commercial dairy herd located at Cairo- Alexandria desert road and named AlexandriaCopenhagen Company far from Alexandria by about $76 \mathrm{~km}$. Data of productive and reproductive records of Holstein Friesian cows were obtained and represented the period from 1998 to 2010. The total number of lactation records was 3460 of 1059 dairy cows which were sired by 96 sires and of 513 dams. Productive traits included were total milk yield (TMY), fat yield (FY), protein yield (PY), days in milk (DIM) and dry period (DP) while the reproductive traits were days open (DO), calving interval (CI) and age at first calving (AFC) and number of services per conception (NSC). Records involved in analysis represented the first two lactations.

Data management and limitation:

Non-normal lactation records were excluded from the analysis. Edits were performed to remove records that were incomplete, had errors in sire identifications and for sires having less than five daughters. Age at first calving was modified to be involved in the analysis per months instead of years by multiplication of the original data by 12 .

\section{Statistical models:}

Data were statistically analyzed using the Least Squares Mixed Model and Maximum Likelihood (LSMLMW) computer program of Harvey (1990). Data of milk production traits were included in the analysis. Statistical sire models involved were mixed as it included two parts; the first part was fixed effect of non-genetic factors as the year of calving and season of calving on all studied traits, while the second part was random including the sire effect as genetic portion on all studied traits. For productive traits (Total milk yield, fat yield, protein yield, days in milk, and dry period), both age at first calving and days open were used as covariates in the model in the form of linear and quadratic regression analyses. On the other hand, the linear and quadratic regression analyses of reproductive traits were fitted on both age at first calving and total milk yield. The following 
statistical mixed model was used for analysis of productive traits:

$\mathbf{Y}_{\mathbf{i j k} \mathbf{m} n}=\boldsymbol{\mu}+\mathbf{S}_{\mathbf{i}}+\mathbf{Y r}_{\mathbf{j}}+\mathbf{M}_{\mathbf{k}}+\beta_{\mathbf{L} 1}$ $\left(\mathrm{AFC}_{\mathrm{L}}\right)+\beta_{\mathrm{Q} 1}\left(\mathrm{AFC}_{\mathrm{L}}\right)^{2}+\beta_{\mathrm{L} 2}$ $\left(\right.$ DOm $_{\mathrm{m}}+\beta_{\mathbf{Q} 2}\left(\mathbf{D O}_{\mathrm{m}}\right)^{2}+\mathbf{e}_{\mathrm{ijk}} \mathrm{mm}$

Where:

$\mathbf{Y}_{\mathbf{i j k l m n}}=$ an observation on animal (Trait value),

$\boldsymbol{\mu}=$ overall mean (mean of trait in population),

$\mathbf{S}_{\mathbf{i}}=$ random effect of $i^{\text {th }}$ sire $(i=1$ 96),

$\mathbf{Y} \mathbf{r}_{\mathbf{j}}=$ fixed effect of year of calving $\mathrm{j}(\mathrm{j}=1998,1999, \ldots, 2010)$,

$\mathbf{M}_{\mathbf{k}}=$ fixed effect of month of calving ( $\mathrm{k}=$ January, February,..., December),

$\beta_{\mathbf{L} 1}=$ linear regression coefficient for $\mathrm{AFC}$,

$\mathbf{A F C}_{\mathbf{L}}=$ covariable of age at first calving (mo),

$\beta$ Q1 $=$ quadratic regression coefficient for AFC,

$\beta_{\mathbf{L} 2}=$ linear regression coefficient for DO,

DO $_{\mathrm{m}}=$ covariable of days open,

$\beta \mathbf{Q 2}=$ quadratic regression coefficient for days open,

$\mathbf{e}_{\mathrm{ijk} k \mathrm{mn}}=$ Residual error and assumed to be independently, randomly distributed with mean zero.

The following statistical mixed model was used for analysis of reproductive traits:

$\mathbf{Y}_{\mathbf{i j k l m n}}=\boldsymbol{\mu}+\mathbf{S}_{\mathbf{i}}+\mathbf{Y r}_{\mathbf{j}}+\mathbf{M}_{\mathbf{k}}+\beta_{\mathbf{L} \mathbf{1}}$

$\left(\mathrm{AFC}_{L}\right)+\beta$ Q1 $\left(\mathrm{AFCL}_{\mathrm{L}}\right)^{2}+\beta_{\mathrm{L} 2}$ $\left(\mathbf{T M Y}_{\mathrm{m}}\right)+\beta_{\mathrm{Q} 2}\left(\mathrm{TMY}_{\mathrm{m}}\right)^{2}+\mathrm{e}_{\mathrm{ijkl} m \mathrm{n}}$

\section{Where:}

$\mathbf{Y}_{\mathbf{i j k} \mathbf{m} n}=$ an observation on animal (trait value),

$\boldsymbol{\mu}=$ overall mean (mean of trait in population),

$\mathbf{S}_{\mathbf{i}}=$ random effect of $i^{\text {th }}$ sire $(i=1$ 96),

$\mathbf{Y} \mathbf{r}_{\mathbf{j}}=$ fixed effect of year of calving $\mathrm{j}(\mathrm{j}=1998,1999, \ldots, 2010)$,

$\mathbf{M}_{\mathbf{k}}=$ fixed effect of month of calving ( $k=$ January, February,..., December),

$\beta_{\mathbf{L} 1}=$ linear regression coefficient for AFC,

$\mathbf{A F C}_{\mathbf{L}}=$ covariable of age at first calving (mo),

$\beta \quad \mathbf{Q 1}=$ quadratic regression coefficient for AFC,

$\beta_{\mathbf{L} 2}=$ linear regression coefficient for TMY,

$\mathbf{T M Y}_{\mathrm{m}}=$ covariable of total milk yield,

$\beta \quad \mathbf{Q} 2=$ quadratic regression coefficient for total milk yield,

$\mathbf{e}_{\mathbf{i j k} \mathbf{m} n}=$ Residual error and assumed to be independently, randomly distributed with mean zero.

Further analysis for means separations was used as multiple comparisons among unequal subclass means and carried out according to Duncan's Multiple Range Test (1955) by (SAS, 2002) computer program. The results were considered significant at $(\mathrm{P} \leq 0.05)$.

\section{RESULTS AND DISCUSSION}

A summary statistics (unadjusted overall means, standard deviations and coefficient of variations) for productive traits of Holstein- 
Friesian cows are shown in Table (1). The mean and standard deviation of each trait were estimated across two parities. The mean total milk yield was highest in the first lactation as $8954 \mathrm{~kg}$ with standard deviation of $3489 \mathrm{~kg}$. The mean annual milk yields were higher than those estimated by Olesen et al (1999) and Bajwa et al (2004) for the same lactations. The means and their standard deviations for days in milk were measured as $398.8 \pm 126.6$ and $355.2 \pm 100.2$ days for the two lactations, respectively. Days in milk were found to be 398.8 and 355.2 days within average for the two lactations, respectively. These results indicated that the current herd had high milk yield in the two lactations.
Table (2) showed the measures of unadjusted overall means, standard deviations and coefficients of variations for the reproductive traits analyzed in this study. The mean age at first calving was 33.38 month with standard deviation of 5.48 month. The mean numbers of services per conception increased from the first to second lactation. Days open were averaged as 185.9 and 155.5, respectively, while calving interval was 434.0 days. These results were near to the findings of (Cilek and Sahin, 2009). These values recommended low reproductive performance of animals under high level of production.

Table (1): Overall (unadjusted) Means, Standard Deviations (S.D.) and Coefficients of Variations (C.V.) for the Productive Studied Traits of First Two Lactations

\begin{tabular}{|c|c|c|c|c|}
\hline Lactation & Trait & Mean & S.D. & C.V. (\%) \\
\hline \multirow{4}{*}{ First } & Days in Milk (DIM) & 398.8 & 126.6 & 31.74 \\
\cline { 2 - 5 } & Total Milk yield / kg & 8954 & 3489 & 38.96 \\
\cline { 2 - 5 } & Fat yield (kg) & 268.0 & 100.8 & 37.61 \\
\cline { 2 - 5 } & Protein yield (kg) & 218.9 & 83.28 & 38.04 \\
\cline { 2 - 5 } & Dry period & - & - & - \\
\hline \multirow{5}{*}{ Second } & Days in Milk (DIM) & 355.2 & 100.2 & 28.21 \\
\cline { 2 - 5 } & Total Milk yield / kg & 8686 & 3082 & 35.48 \\
\cline { 2 - 5 } & Fat yield (kg) & 264.1 & 100.0 & 37.86 \\
\cline { 2 - 5 } & Protein yield (kg) & 220 & 84.28 & 38.30 \\
\cline { 2 - 5 } & Dry period & 76.71 & 69.11 & 90.09 \\
\cline { 2 - 5 } & Peak milk yield & 75.97 & 52.23 & 68.75 \\
\cline { 2 - 5 } & Dry period & 78.05 & 68.19 & 87.36 \\
\hline
\end{tabular}


Table (2): Overall (unadjusted) Means, Standard Deviations and Coefficients of Variations for the Reproductive Studied Traits of First Two Lactations

\begin{tabular}{|c|c|c|c|c|}
\hline Lactation & Trait & Mean & S.D. & $\begin{array}{c}\text { C.V. } \\
(\boldsymbol{\%})\end{array}$ \\
\hline \multirow{4}{*}{ First } & Age at first calving (month) & 33.38 & 5.48 & 16.41 \\
\cline { 2 - 5 } & $\begin{array}{c}\text { Services per conception } \\
\text { (number) }\end{array}$ & 2.00 & 1.77 & 88.5 \\
\cline { 2 - 5 } & Days open & 185.9 & 131.7 & 70.8 \\
\cline { 2 - 5 } Second & Calving interval & - & - & - \\
\hline \multirow{3}{*}{} & Services per conception & 3.16 & 2.15 & 68.0 \\
\cline { 2 - 5 } & Days open & 155.5 & 120.0 & 77.17 \\
\cline { 2 - 5 } & Calving interval & 434.0 & 111.6 & 25.58 \\
\hline
\end{tabular}

Tables (3-6) represent the effect of fixed (non-genetic) and random factors on the studied productive and reproductive traits for the data of the first two lactations. The fixed effects were the year and season of calving, and the random effect was included in the model as sire effect for genetic evaluation of the dairy farm. In addition, the model contained the linear and quadratic regression of productive traits on age at first calving and days open, and the linear and quadratic regression of reproductive traits on age at first calving and total milk. In other words, age at first calving, days open and total milk were fitted as covariates. Tables (3-6) obtained as the result of the mixed model least squares analysis of variance of Harvey (1990).

Year of calving had a significant effect $(\mathrm{P} \leq 0.05)$ on all studied productive traits except for days in milk, total milk yield and dry period in second lactation. Also, year of calving had a significant $(\mathrm{P} \leq 0.05)$ effect on reproductive traits except for number of services per conception in first lactation. Similar findings were found by Mohamed, 1987; Djemali and Berger, 1992 and Lee et al, 2003. Season of calving had a significant $(\mathrm{P} \leq 0.05)$ effect on all studied traits except for fat yield, dry period and days open in second lactation and number of services per conception in two lactations. As shown in tables $(3,4$, 5 and 6$)$ sire had a significant $(\mathrm{P} \leq$ 0.05 ) effect on all studied traits that indicate genetic variations and possibility of genetic improvement of this herd together with interest of environment.

Linear regression coefficients on age at first calving were significant for total milk yield, fat yield and protein yield in second lactation, while the quadratic coefficients on the same covariate were nonsignificant for all studied traits. Linear regression coefficients on 
days open were significant for all productive traits, while the quadratic coefficients were significant for all traits except for total milk yield in $1^{\text {st }}$ lactation and dry period in second lactation. In addition, linear and quadratic regression coefficients on total milk yield were significant for most of reproductive traits as the finding of Scott et al (1996).

Table (3): Combined Least Squares Analysis of Variances for the Studied Factors Affecting Productive Traits for the First Lactation

\begin{tabular}{|c|c|c|c|c|c|}
\hline & & \multicolumn{4}{|c|}{ Mean squares } \\
\cline { 3 - 6 } Source of variation & D.F. & DIM & TMY & Fat yield & $\begin{array}{c}\text { Protein } \\
\text { yield }\end{array}$ \\
\hline Sire & 95 & $7305^{*}$ & $14793976^{* *}$ & $18848.4^{* *}$ & $10528.13^{* *}$ \\
\hline Year of calving & 10 & $10202^{*}$ & $30849666^{* *}$ & $34218.7^{* *}$ & $24716.13^{* *}$ \\
\hline Season of calving & 11 & $2860.99^{*}$ & $8796167^{*}$ & $3473.41^{*}$ & $2984.86^{*}$ \\
\hline $\begin{array}{c}\text { Regression on AFC } \\
\text { (linear) }\end{array}$ & 1 & 4283.78 & 4289472 & 14590.0 & 3465.66 \\
\hline $\begin{array}{c}\text { Regression on AFC } \\
\text { (quadratic) }\end{array}$ & 1 & 4319.28 & 28827 & 12878.84 & 8325.74 \\
\hline $\begin{array}{c}\text { Regression on DO } \\
\text { (linear) }\end{array}$ & 1 & $4926217^{* *}$ & $1093836663^{* *}$ & $765627.3^{* *}$ & $519762.9^{* *}$ \\
\hline $\begin{array}{c}\text { Regression on DO } \\
\text { (quadratic) }\end{array}$ & 1 & $153709^{* *}$ & 6265382 & $165832.86^{* *}$ & $108726.58^{* *}$ \\
\hline Error & 938 & 5673.66 & 8157419 & 7422.135 & 5102.76 \\
\hline
\end{tabular}

Table (4): Combined Least Squares Analysis of Variances for the Studied Factors Affecting Productive Traits for the Second Lactation

\begin{tabular}{|c|c|c|c|c|c|c|}
\hline & & \multicolumn{5}{|c|}{ Mean squares } \\
\cline { 4 - 7 } Source of variation & D.F. & DIM & TMY & $\begin{array}{c}\text { Fat } \\
\text { yield }\end{array}$ & $\begin{array}{c}\text { Prot. } \\
\text { Yield }\end{array}$ & $\begin{array}{c}\text { Dry } \\
\text { period }\end{array}$ \\
\hline Sire & 95 & $8834^{* *}$ & $17777653^{* *}$ & $22115^{* *}$ & $13810^{* *}$ & $10190^{* *}$ \\
\hline Year of calving & 10 & 6945 & 6613525 & $24344^{* *}$ & $18067^{* *}$ & 1534 \\
\hline Season of calving & 11 & $14805^{* *}$ & $13445018^{*}$ & 12144 & $10709^{*}$ & 1694 \\
\hline $\begin{array}{c}\text { Regression on AFC } \\
\text { (linear) }\end{array}$ & 1 & 13209 & $67875286^{* *}$ & $65570^{* *}$ & $55361^{* *}$ & 5533 \\
\hline $\begin{array}{c}\text { Regression on AFC } \\
\text { (quadratic) }\end{array}$ & 1 & 20240 & 1461533 & 20.06 & 1998 & 177.6 \\
\hline $\begin{array}{c}\text { Regression on DO } \\
\text { (linear) }\end{array}$ & 1 & $1823910^{* *}$ & $565600091^{* *}$ & $500429^{* *}$ & $370409^{* *}$ & $86451^{* *}$ \\
\hline $\begin{array}{c}\text { Regression on DO } \\
\text { (quadratic) }\end{array}$ & 1 & $199931^{* *}$ & $139053197^{* *}$ & $187566^{* *}$ & $117437^{* *}$ & 5.641 \\
\hline Error & 938 & 6082 & 7228868 & 7358 & 5127 & 3903 \\
\hline
\end{tabular}


Table (5): Combined Least Squares Analysis of Variances for the Studied Factors Affecting Reproductive Traits for the First Lactation

\begin{tabular}{|c|c|c|c|}
\hline & \multirow{2}{*}{ Source of variation } & D.F. & \multicolumn{2}{|c|}{ Mean squares } \\
\cline { 3 - 4 } & 95 & $10.865^{* *}$ & Days open \\
\hline Sire & 10 & 2.875 & $15393.2^{* * *}$ \\
\hline Year of calving & 11 & 3.099 & $391407.1^{* *}$ \\
\hline Season of calving & 1 & 1.036 & 133.15 \\
\hline Regression on AFC (linear) & 1 & 0.999 & 566.07 \\
\hline Regression on AFC (quadratic) & 1 & $12.525^{* *}$ & $1868934^{* *}$ \\
\hline Regression on TMY (linear) & 1 & $17.17^{* *}$ & $396828.4^{* *}$ \\
\hline Regression on TMY (quadratic) & 1 & 2.238 & 10693.5 \\
\hline Error & 938 & &
\end{tabular}

Table (6): Combined Least Squares Analysis of Variances for the Studied Factors Affecting Reproductive Traits for the Second Lactation

\begin{tabular}{|c|c|c|c|c|}
\hline & & \multicolumn{3}{|c|}{ Mean squares } \\
\cline { 3 - 5 } Source of variation & D.F. & S/C & Days open & Calving interval \\
\hline Sire & 95 & $10.77^{* *}$ & $15130^{*}$ & $16100^{* *}$ \\
\hline Year of calving & 10 & $8.995^{* *}$ & $59774^{* *}$ & $64686^{* *}$ \\
\hline Season of calving & 11 & 3.418 & 15599 & $28255^{* *}$ \\
\hline $\begin{array}{c}\text { Regression on AFC } \\
\text { (linear) }\end{array}$ & 1 & $15.16^{*}$ & 76.17 & 11742 \\
\hline $\begin{array}{c}\text { Regression on AFC } \\
\text { (quadratic) }\end{array}$ & 1 & 1.961 & 1907 & 36481 \\
\hline $\begin{array}{c}\text { Regression on TMY } \\
\text { (linear) }\end{array}$ & 1 & 11.01 & $872612^{* *}$ & 7732 \\
\hline $\begin{array}{c}\text { Regression on TMY } \\
\text { (quadratic) }\end{array}$ & 1 & $48.14^{* *}$ & $698614^{* *}$ & $77418^{* *}$ \\
\hline Error & 938 & 3.822 & 11512 & 10713 \\
\hline
\end{tabular}

As given in Tables (7, 8, 9 and 10), the adjusted means and their standard errors were calculated for productive and reproductive traits that showed the effect of year of calving (from 1998 to 2010), season of calving (from January to December) as well as the linear and quadratic regression coefficients of the productive traits on age at first calving, days open and total milk yield. The overall adjusted means and their standard errors of total milk yield were $8783 \pm 246.5$ and $8831 \pm 294$, for the first two lactations, respectively. Similar results were reported by Tekerli and Gundogan (2005). In general, total milk yield was highest in later years of calving in all lactation compared with early years of calving. Little seasonal variations were observed for milk production, where the yield was higher from May to August compared with other months of the year.The variation of milk yield from one year to another, and from parity to another could be attributed to changes in herd size, age of animals and good management practices from lactation to another. This conclusion agrees with the 
finding of Rege (1991); Atil et al (2001) and Amino et al (2007). The overall adjusted means and their standard errors of days in milk were $401.8 \pm 5.13$ and $370.53 \pm 6.08$ for the first two lactations, respectively. These results were lower than those estimated by Bajwa et al (2004). The higher days in milk in the original farm data in the first lactation was the cause of increasing the value of its mean especially that we found some cows had days in milk greater than 600 days.

The overall adjusted means and their standard errors of fat and protein yields were $272.58 \pm 9.16$ and $267.8 \pm 10.6$ for fat yield, and were $219.96 \pm 6.69$ and $224.9 \pm 8.3$ for protein yield $1^{\text {st }}$ and $2^{\text {nd }}$ lactations, respectively. This result showed that these traits had the same trend as occurred total milk yield. The estimate for dry period was $75.01 \pm 7.08$ for the $2^{\text {nd }}$ lactation. It was clear that dry period increased with calving age of cows. Similar results were reported recently by M'hamdi et al (2012) on Holstein cows. Absence of seasonal variations in dry period could be attributed to management and the fixed ration allover the year round.On the other hand, adjusted means and their standard errors of the number of services per conception were $2.22 \pm 0.22$ and $2.75 \pm 0.23$, respectively. As shown, the number of services required increased as the age of cow increased; this may be due to reproductive inefficiency of cows in the farm which is antagonistic with milk yield as seen from the results. Similarly, the adjusted means of days open were higher than the ideal values and may indicate reproductive problems in the farm. The estimates of days open were 192.48 \pm 7.45 and 154.27 \pm 7.79 , for the first and second lactations, respectively. The result of the present study is in accordance with the finding of Ibrahim et al (2002), but higher than the findings of Ojango (2000) who found that the averages of days open were 127, 112,115 and 104 days for the same lactations, respectively. The result showed that the adjusted mean of age at first calving was $29.75 \pm 0.40$ month for the herd. Ages at first calving were ranged from 25.5 to 34.6 months across all years of calving. The variation in the values of age at first calving may be the cause of its significant effect on most of productive and reproductive traits specially that AFC was used as covariate in all models.

The adjusted mean \pm standard error of calving interval was $442.91 \pm 8.26$, for the second, lactation. The present study showed the significant effect of total milk yield as covariate on calving interval. These estimates of CI were near the results obtained by Ibrahim et al (2002) who found CI means as 358.6, 430, 432, and 462 for the first five lactations. 
Table (7): Adjusted Least Square Means and Standard Errors of the Fixed Effects and Covariates on Productive Traits for the First Lactation

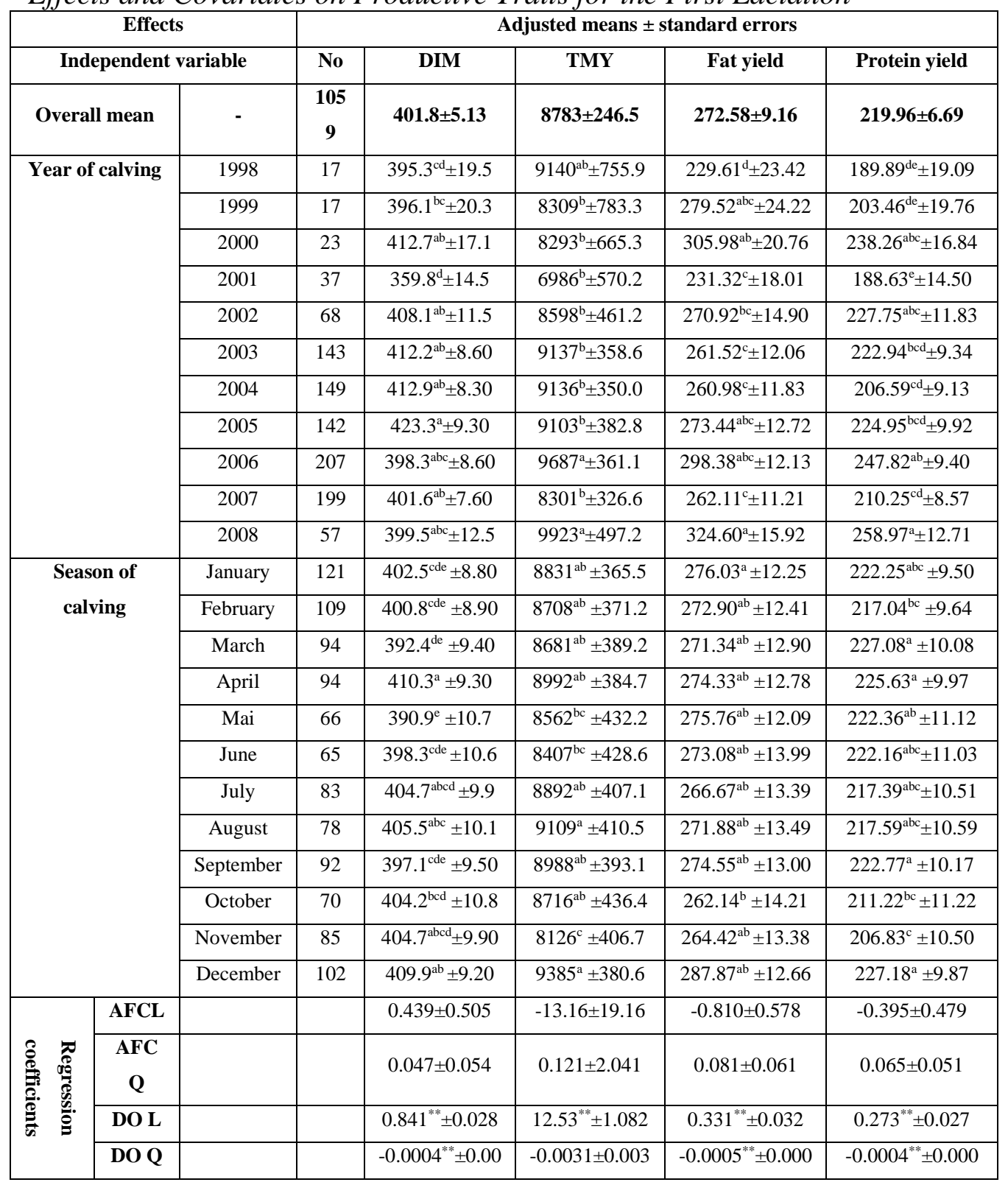


Table (8): Adjusted Least Square Means and Standard Errors of the Fixed Effects and Covariates on Reproductive Traits for the First Lactation

\begin{tabular}{|c|c|c|c|c|c|c|c|}
\hline \multicolumn{5}{|c|}{ Effects } & \multicolumn{3}{|c|}{ Adjusted means \pm standard errors } \\
\hline \multicolumn{4}{|c|}{ Independent variable } & No & SC & DO & AFC-month \\
\hline \multicolumn{3}{|c|}{ Overall mean } & - & 105 & $2.22 \pm 0.22$ & $192.48 \pm 7.45$ & $29.75 \pm 0.40$ \\
\hline \multirow{11}{*}{\multicolumn{3}{|c|}{ 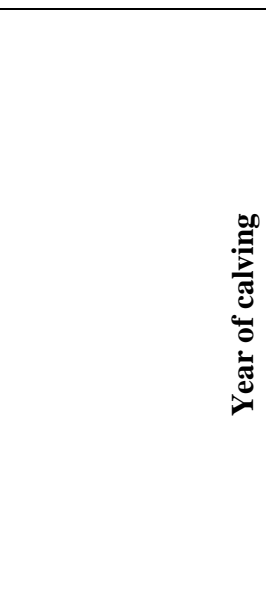 }} & 1998 & 17 & $2.65^{\mathrm{a}} \pm 0.43$ & $188.09^{\mathrm{bc}} \pm 26.97$ & $31.38^{\mathrm{bcd}} \pm 1.28$ \\
\hline & & & 1999 & 17 & $2.38^{\mathrm{a}} \pm 0.45$ & $241.20^{\mathrm{bc}} \pm 27.91$ & $34.60^{\mathrm{a}} \pm 1.31$ \\
\hline & & & 2000 & 23 & $2.43^{\mathrm{a}} \pm 0.39$ & $205.47^{\mathrm{bc}} \pm 23.61$ & $31.91^{\mathrm{bc}} \pm 1.13$ \\
\hline & & & 2001 & 37 & $1.93^{\mathrm{a}} \pm 0.35$ & $297.27^{b} \pm 19.76$ & $32.02^{\mathrm{ab}} \pm 0.95$ \\
\hline & & & 2002 & 68 & $1.92^{\mathrm{a}} \pm 0.30$ & $247.08^{\mathrm{bc}} \pm 15.79$ & $29.69^{\text {cde }} \pm 0.77$ \\
\hline & & & 2003 & 143 & $2.10^{\mathrm{a}} \pm 0.26$ & $186.25^{\mathrm{cd}} \pm 12.07$ & $30.62^{\mathrm{bcd}} \pm 0.61$ \\
\hline & & & 2004 & 149 & $1.91^{\mathrm{a}} \pm 0.26$ & $177.25^{\mathrm{cd}} \pm 11.66$ & $29.76^{\mathrm{bcd}} \pm 0.56$ \\
\hline & & & 2005 & 142 & $2.32^{\mathrm{a}} \pm 0.27$ & $166.04^{\mathrm{de}} \pm 12.91$ & $28.41^{\mathrm{def}} \pm 0.64$ \\
\hline & & & 2006 & 207 & $2.49^{\mathrm{a}} \pm 0.26$ & $167.34^{\mathrm{cd}} \pm 12.24$ & $25.53^{\mathrm{f}} \pm 0.60$ \\
\hline & & & 2007 & 199 & $2.15^{\mathrm{a}} \pm 0.25$ & $145.95^{\mathrm{e}} \pm 10.97$ & $26.69^{f} \pm 0.53$ \\
\hline & & & 2008 & 57 & $2.19^{\mathrm{a}} \pm 0.31$ & $95.31^{\mathrm{a}} \pm 16.86$ & $26.73^{\mathrm{ef}} \pm 0.82$ \\
\hline \multirow{12}{*}{\multicolumn{3}{|c|}{ 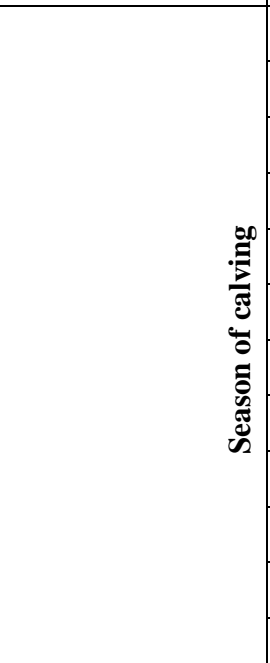 }} & January & 121 & $2.37^{\mathrm{a}} \pm 0.26$ & $187.96^{\mathrm{bc}} \pm 12.18$ & $30.19^{\mathrm{a}} \pm 0.61$ \\
\hline & & & February & 109 & $2.09^{\mathrm{a}} \pm 0.26$ & $212.93^{\mathrm{ab}} \pm 12.43$ & $30.39^{\mathrm{a}} \pm 0.62$ \\
\hline & & & March & 94 & $1.91^{\mathrm{a}} \pm 0.27$ & $213.94^{\mathrm{ab}} \pm 13.21$ & $29.64^{\mathrm{a}} \pm 0.65$ \\
\hline & & & April & 94 & $2.02^{\mathrm{a}} \pm 0.27$ & $228.60^{\mathrm{a}} \pm 13.06$ & $30.38^{a} \pm 0.65$ \\
\hline & & & Mai & 66 & $2.14^{\mathrm{a}} \pm 0.29$ & $204.66^{\mathrm{ab}} \pm 14.93$ & $29.94^{\mathrm{a}} \pm 0.73$ \\
\hline & & & June & 65 & $2.11^{\mathrm{a}} \pm 0.29$ & $222.65^{\mathrm{ab}} \pm 14.74$ & $29.76^{\mathrm{a}} \pm 0.72$ \\
\hline & & & July & 83 & $2.23^{\mathrm{a}} \pm 0.28$ & $184.98^{\mathrm{cd}} \pm 13.83$ & $28.49^{a} \pm 0.67$ \\
\hline & & & August & 78 & $2.48^{\mathrm{a}} \pm 0.28$ & $155.83^{\mathrm{d}} \pm 13.94$ & $28.97^{\mathrm{a}} \pm 0.68$ \\
\hline & & & September & 92 & $2.46^{\mathrm{a}} \pm 0.27$ & $175.30^{\mathrm{cd}} \pm 13.31$ & $29.33^{\mathrm{a}} \pm 0.65$ \\
\hline & & & October & 70 & $2.44^{\mathrm{a}} \pm 0.29$ & $179.08^{\mathrm{cd}} \pm 14.97$ & $29.76^{a} \pm 0.73$ \\
\hline & & & November & 85 & $2.03^{\mathrm{a}} \pm 0.28$ & $170.59^{\mathrm{cd}} \pm 13.93$ & $30.45^{\mathrm{a}} \pm 0.68$ \\
\hline & & & December & 102 & $2.40^{\mathrm{a}} \pm 0.27$ & $173.21^{\mathrm{cd}} \pm 12.83$ & $29.77^{\mathrm{a}} \pm 0.64$ \\
\hline \multirow{4}{*}{\multicolumn{2}{|c|}{ 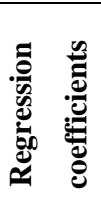 }} & AFC L & & & $0.007 \pm 0.010$ & $0.077 \pm 0.694$ & No regression \\
\hline & & AFC Q & & & $0.0007 \pm 0.001$ & $-0.016 \pm 0.074$ & No regression \\
\hline & & TMY L & & & $0.0000^{* *} \pm 00000$ & $0.014^{* *} \pm 0.001$ & No regression \\
\hline & & TMY Q & & & $0.0000^{* *} \pm 0.0000$ & $0.000^{* *} \pm 0.000$ & No regression \\
\hline
\end{tabular}


Table (9): Adjusted Least Square Means and Standard Errors of the Fixed Effects and Covariates on Productive Traits of the Second Lactation

\begin{tabular}{|c|c|c|c|c|c|c|c|c|}
\hline \multicolumn{4}{|c|}{ Effects } & \multicolumn{5}{|c|}{ Adjusted means \pm standard errors } \\
\hline \multicolumn{3}{|c|}{ Independent variable } & No & DIM & TMY & Fat yield & Protein yield & Dry period \\
\hline \multicolumn{2}{|c|}{ Overall mean } & - & 1059 & $370.53 \pm 6.08$ & $8831 \pm 294$ & $267.8 \pm 10.6$ & $224.9 \pm 8.3$ & $75.01 \pm 7.08$ \\
\hline \multirow{11}{*}{\multicolumn{2}{|c|}{ 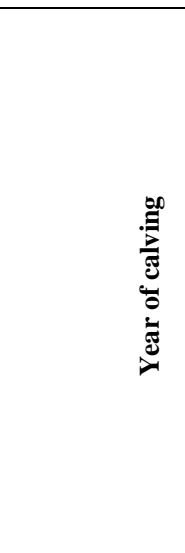 }} & 1999 & 16 & $361.14^{\mathrm{a}} \pm 21.20$ & $8908^{\mathrm{a}} \pm 759$ & $284.7^{\mathrm{ab}} \pm 24.7$ & $217.9^{\mathrm{abc}} \pm 20.4$ & $74.37^{\mathrm{a}} \pm 17.74$ \\
\hline & & 2000 & 13 & $358.29^{\mathrm{a}} \pm 23.85$ & $7736^{\mathrm{a}} \pm 847$ & $258.6^{\mathrm{abc}} \pm 27.5$ & $214.2^{\mathrm{bc}} \pm 22.7$ & $65.08^{\mathrm{a}} \pm 19.78$ \\
\hline & & 2001 & 26 & $394.57^{\mathrm{a}} \pm 17.07$ & $8252^{\mathrm{a}} \pm 623$ & $225.7^{c} \pm 20.5$ & $211.0^{\mathrm{bc}} \pm 16.8$ & $63.90^{\mathrm{a}} \pm 14.61$ \\
\hline & & 2002 & 27 & $392.09^{\mathrm{a}} \pm 17.13$ & $9106^{\mathrm{a}} \pm 625$ & $264.3^{\mathrm{abc}} \pm 20.5$ & $220.3^{\mathrm{abc}} \pm 16.9$ & $80.63^{\mathrm{a}} \pm 14.65$ \\
\hline & & 2003 & 61 & $374.42^{\mathrm{a}} \pm 11.91$ & $8655^{\mathrm{a}} \pm 459$ & $241.3^{\mathrm{bc}} \pm 15.4$ & $216.8^{\mathrm{abc}} \pm 12.5$ & $79.96^{\mathrm{a}} \pm 10.84$ \\
\hline & & 2004 & 127 & $379.06^{\mathrm{a}} \pm 9.72$ & $8915^{\mathrm{a}} \pm 393$ & $242.7^{\mathrm{bc}} \pm 13.5$ & $193.5^{\mathrm{c}} \pm 10.8$ & $72.88^{\mathrm{a}} \pm 9.33$ \\
\hline & & 2005 & 170 & $374.24^{\mathrm{a}} \pm 8.58$ & $9303^{\mathrm{a}} \pm 360$ & $267.4^{\mathrm{abc}} \pm 12.5$ & $235.5^{\mathrm{ab}} \pm 9.9$ & $78.81^{\mathrm{a}} \pm 8.58$ \\
\hline & & 2006 & 134 & $365.57^{\mathrm{a}} \pm 9.67$ & $9427^{\mathrm{a}} \pm 392$ & $291.9^{\mathrm{ab}} \pm 13.4$ & $248.0^{\mathrm{a}} \pm 10.8$ & $70.52^{\mathrm{a}} \pm 9.30$ \\
\hline & & 2007 & 213 & $357.78^{\mathrm{a}} \pm 8.95$ & $8803^{\mathrm{a}} \pm 371$ & $280.5^{\mathrm{abc}} \pm 12.8$ & $227.0^{\mathrm{abc}} \pm 10.2$ & $82.14^{\mathrm{a}} \pm 8.82$ \\
\hline & & 2008 & 205 & $370.21^{\mathrm{a}} \pm 8.09$ & $9070^{\mathrm{a}} \pm 346$ & $287.1^{\mathrm{ab}} \pm 12.1$ & $235.8^{\mathrm{a}} \pm 9.6$ & $77.31^{\mathrm{a}} \pm 8.27$ \\
\hline & & 2009 & 67 & $348.46^{\mathrm{a}} \pm 12.07$ & $8962^{\mathrm{a}} \pm 464$ & $302.6^{\mathrm{a}} \pm 15.6$ & $254.2^{\mathrm{a}} \pm 12.7$ & $79.56^{\mathrm{a}} \pm 10.95$ \\
\hline \multirow{12}{*}{\multicolumn{2}{|c|}{ 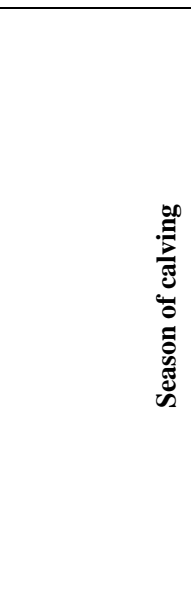 }} & January & 108 & $372.58^{\mathrm{bcd}} \pm 9.93$ & $8835^{\mathrm{ab}} \pm 399$ & $259.4^{\mathrm{a}} \pm 13.6$ & $215.3^{\mathrm{bc}} \pm 10.9$ & $66.91^{\mathrm{a}} \pm 9.47$ \\
\hline & & February & 99 & $378.20^{\text {abcd }} \pm 9.98$ & $8759^{\mathrm{ab}} \pm 401$ & $254.4^{\mathrm{a}} \pm 13.7$ & $211.1^{\mathrm{bc}} \pm 11.0$ & $81.00^{\mathrm{a}} \pm 9.50$ \\
\hline & & March & 68 & $389.88^{\mathrm{ab}} \pm 11.53$ & $8913^{\mathrm{ab}} \pm 447$ & $275.4^{\mathrm{a}} \pm 15.1$ & $230.9^{\mathrm{ab}} \pm 12.2$ & $77.59^{\mathrm{a}} \pm 10.57$ \\
\hline & & April & 50 & $391.59^{\mathrm{a}} \pm 12.98$ & $9567^{\mathrm{a}} \pm 492$ & $282.7^{\mathrm{a}} \pm 16.4$ & $241.3^{\mathrm{ab}} \pm 13.4$ & $70.04^{\mathrm{a}} \pm 11.60$ \\
\hline & & Mai & 47 & $380.82^{\mathrm{abcd}} \pm 13.39$ & $9434^{\mathrm{ab}} \pm 505$ & $279.8^{\mathrm{a}} \pm 16.8$ & $235.8^{\mathrm{ab}} \pm 13.7$ & $83.09^{\mathrm{a}} \pm 11.89$ \\
\hline & & June & 64 & $383.51^{\mathrm{abc}} \pm 11.83$ & $9566^{\mathrm{a}} \pm 457$ & $293.4^{\mathrm{a}} \pm 15.4$ & $247.7^{\mathrm{a}} \pm 12.5$ & $71.05^{\mathrm{a}} \pm 10.78$ \\
\hline & & July & 74 & $366.16^{\mathrm{cde}} \pm 10.88$ & $8669^{\mathrm{ab}} \pm 428$ & $261.6^{\mathrm{a}} \pm 14.5$ & $220.8^{\mathrm{bc}} \pm 11.7$ & $69.60^{\mathrm{a}} \pm 10.12$ \\
\hline & & August & 90 & $355.89^{\mathrm{de}} \pm 10.41$ & $8028^{\mathrm{b}} \pm 413$ & $242.6^{\mathrm{a}} \pm 14.1$ & $200.8^{\mathrm{c}} \pm 11.3$ & $75.81^{\mathrm{a}} \pm 9.79$ \\
\hline & & September & 125 & $370.45^{\text {bcd }} \pm 9.34$ & $8337^{b} \pm 382$ & $258.7^{\mathrm{a}} \pm 13.1$ & $219.4^{\mathrm{bc}} \pm 10.5$ & $77.07^{\mathrm{a}} \pm 9.08$ \\
\hline & & October & 128 & $354.23^{\mathrm{de}} \pm 9.01$ & $8662^{\mathrm{b}} \pm 372$ & $270.1^{\mathrm{a}} \pm 12.8$ & $224.9^{\mathrm{bc}} \pm 10.3$ & $78.22^{\mathrm{a}} \pm 8.86$ \\
\hline & & November & 114 & $357.80^{\mathrm{de}} \pm 9.59$ & $8579^{\mathrm{b}} \pm 389$ & $263.2^{\mathrm{a}} \pm 13.3$ & $225.0^{\mathrm{bc}} \pm 10.7$ & $73.39^{\mathrm{a}} \pm 9.25$ \\
\hline & & December & 92 & $345.25^{\mathrm{e}} \pm 10.17$ & $8620^{b} \pm 406$ & $272.3^{\mathrm{a}} \pm 13.8$ & $226.0^{\mathrm{abc}} \pm 11.2$ & $76.41^{\mathrm{a}} \pm 9.63$ \\
\hline \multirow{4}{*}{ 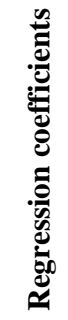 } & AFCL & & & $-0.768 \pm 0.522$ & $-1.71 \pm 0.57$ & $-1.6^{* *} \pm 0.48$ & $0.497 \pm 0.417$ & $0.497 \pm 0.417$ \\
\hline & AFCQ & & & $-0.102 \pm 0.056$ & $0.003 \pm 0.061$ & $-0.032 \pm 0.05$ & $-0.009 \pm 0.004$ & $-0.009 \pm 0.004$ \\
\hline & DO L & & & $0.616^{* *} \pm 0.0355$ & $0.323^{* *} \pm 0.039$ & $0.277^{* *} \pm 0.033$ & $0.134^{* *} \pm 0.028$ & $0.134^{* *} \pm 0.028$ \\
\hline & DO Q & & & $\begin{array}{l}-0.0005^{* *} \\
\pm 0.0009\end{array}$ & $\begin{array}{l}-0.0005^{* *} \\
\pm 0.0001\end{array}$ & $\begin{array}{l}-0.0004^{* *} \\
\pm 0.00008\end{array}$ & $-0.002 \pm 0.007$ & $-0.002 \pm 0.007$ \\
\hline
\end{tabular}


Table (10): Adjusted Least Square Means and Standard Errors of the Fixed Effects and Covariates on Reproductive Traits for the Second Lactation

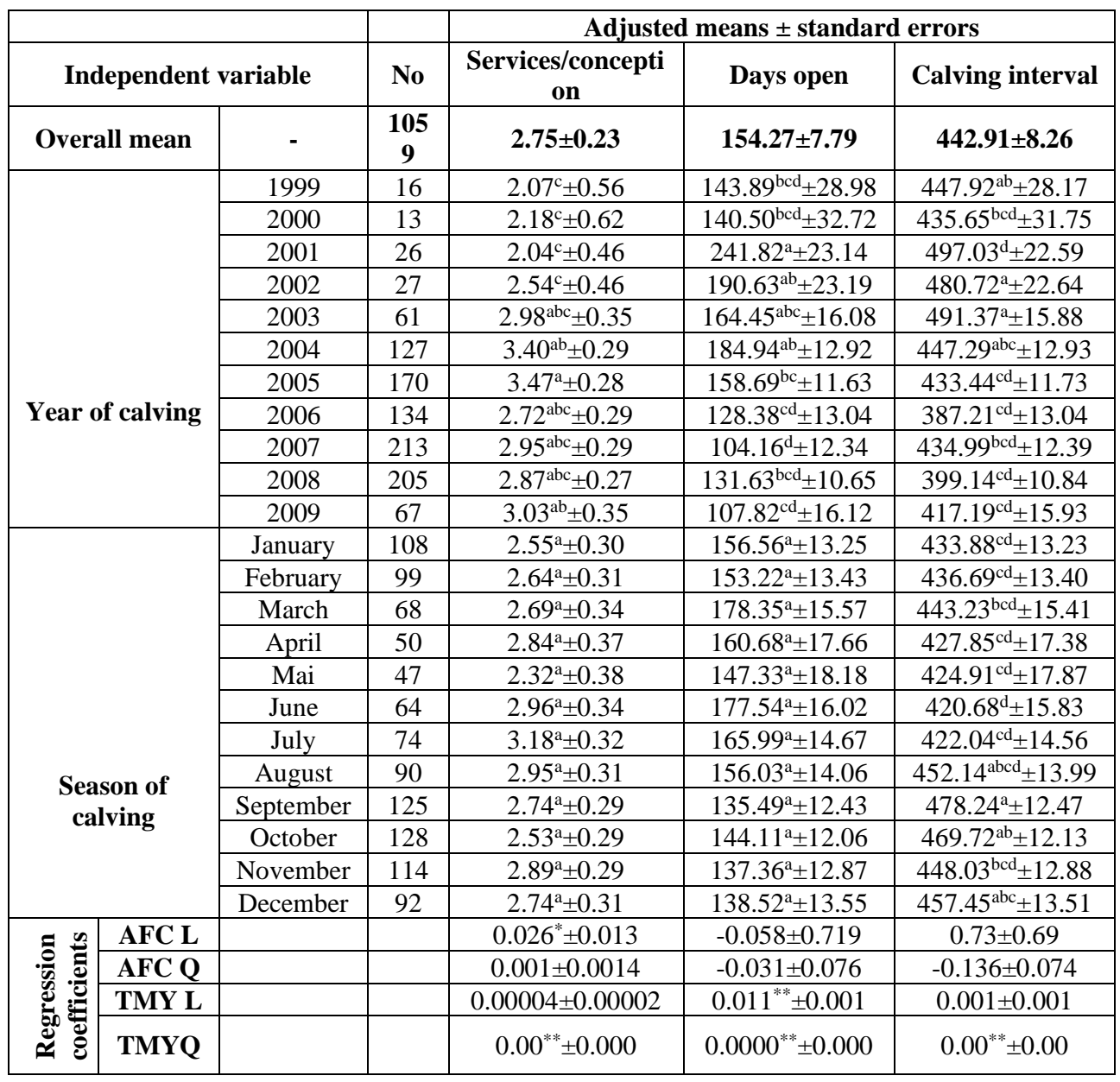

The present study indicated that Holstein dairy farming system in commercial herd in Egypt can show high milk production under adequate management. Existing evidence suggesting that high production is positively correlated to later lactations. However, low reproductive performance was observed in the current herd under the high yielding levels. The significant effect of non-genetic factors such as year and month of calving was observed for most of studied traits. Involving of these fixed effects in the statistical model could be resulted in more accurate and reasonable estimates. 


\section{REFERENCES}

Amimo J.O., R.O. Mosi, J.W. Wakhungu, T.K. Masaya and B.O. Inyangala (2007): Phenotypic and genetic parameters of reproductive traits for Ayrshire cattle on large-scale farms in Kenya. Livestock Research Rural Development, 18 (10).

Atil H., A. S. Khattab and C. Yakupoglu (2001): Genetic analysis for ilk traits in different herds of Holstein Frisian cattle in Turkey. Journal of Biological Science 1(8): 737-741.

Bajwa, I.R., M.S. khan, M.A. khan and K.Z. Gondal (2004): Environmental factors affecting milk yield and lactation length in Sahiwal cattle. Pakistan Vet. J., 24 (1): 23-27.

Cilek, S. and S. Sahin (2009): Estimation of some genetic parameters (heritability and repeatability) for milk yield in the Anatolian population of Holstein cows. Archiva Zootechnica 12:1, 57- 64.

Combellas, J., M. Tesorero, and L. Gabaldon (2003): Effect of calf stimulation during milking on milk production and fat content of Bos indicus $\times$ Bos Taurus cows. Livest. Prod. Sci. 79 (2-3): 227-232.

Das, S.M., H. Wiktorsson and M. Forsberg (1999): Effect of calf management and level of feed supplementation on milk production and calf growth of zebu and crossbreed cattle in the semi-arid tropics. Livest. Prod. Sci. 59, 67-75.
Djemali, M., and P.J. Berger (1981): Yield and reproduction characteristics of Friesian cattle under North African conditions. J. Dairy Sci. 75:3568-3575.

Duncan, D. B. (1955): Multiple range and multiple $\mathrm{F}$ tests, Biometrics, 11, 142.

Epaphras, A., E.D. Karimuribo and S.N. Msellem (2004): Effect of season and parity on lactation of crossbred Ayrshire cows reared under coastal tropical climate in Tanzania. Livest. Res. Rural. Dev. 6 (16) Online: URL: http://www.cipav.org.co//rrd//rrd16/ 6/epap16042.

Galina, C.S., I. Rubio, H. Basurto and A. Orhuela (2001): Consequences of different suckling systems for reproductive activity and productivity of cattle in tropical conditions. Appl. Anim. Behav. Sci. 72, 255-262.

Harvey, W.R. (1990): User's guide for LSMLMW, mixed model least squares and maximum likelihood computer program. PC-2 version 2, Ohio state Univ., Columbus (Mimeograph), USA.

Ibrahim, Z.M.K., A.I., Haider, N.A. Shalaby and M.A.Z. Alemam (2002): evaluation of productive and reproductive performance of Friesian cows raised in Egypt. Proc., $1^{\text {st }}$ Sc. Conf. Anim. And Fish Prod. Mansoura 24 and 25 September.

Lee, D.H., K.J. Han, and B.H. Park (2003): Genetic relationship between milk yields, calving ease 
and days open at first lactation of Holstein cows in Korea. Interbull Bull. 31:122-129.

M'hamdi, N., R. Aloulou, S.K. Bouallegue and Ben M. Hamouda (2010): Phenotypic and genetic parameters of reproductive traits in Tunisian Holstein cows. Biotechnology in Animal Husbandry, 26 (5-6): 297-307.

Mohamed, S.S. (1987): Milk and calf production as affected by calving interval and service period in purebred and crossbred Friesian cows in Egypt. M. Sc. Thesis, Faculty of Agriculture, Ain Shams University, Cairo, Egypt.

Msanga, Y.N., M.J. Bryant, I.B. Rutam, F.N. Minja and L. Zylstra (2000): Effect of environmental factors and of the proportion of Holstein blood on the milk yield and lactation length of crossbred dairy cattle on smallholder farms in north-east Tanzania. Trop. Anim. Health Prod. 32 (1), 23-31.

Ojango, J.M. (2000): Performance of Holstein-Friesian cattle in Kenya and the potential for genetic improvement using international breeding values; $\mathrm{PhD}$ thesis. Wye
University College, university of London.

Olesen I., E. Lindhardt and $M$. Ebbesvik (1999): Effects of calving season and sire's breeding value in a dairy herd during conversion to ecological milk production. Livestock Production Science. 61: 201-211.

Rege, J.E.O. (1991): Genetic analysis of reproductive and productive performance of Friesian cattle in Kenya; Journal Animal Breeding and Genetics 108: 412432.

SAS ${ }^{\circledR}$ 9.1.3 (2002): Fifth Edition, SAS Institute Inc., Cary, NC, USA ISBN 978-1-59994-098-4.

Scott, T.A., B. Yandell, L. Zepeda, R.D. Shaver, and T.R. Smith (1996): Use of lactation curves for analysis of milk production data. J. Dairy Sci. 79:1885-1894.

Tekerli, M., and M. Gundogan (2005): Effect of certain factors on productive and reproductive efficiency traits and phenotypic relationships among these traits and repeatabilities in west Anatolian Holsteins. Turk J. Vet. Anim. Sci. 29: 17-22. 


\section{الملخص العربي}

العوامل الوراثية والغير وراثية التى تؤثر على بعض الصفات الانتاجية والتناسلية لأبقار

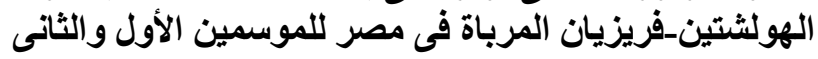

محمد منصور عثمان ، خيرى محمد البيومى' ، شريف عبد الرحمن معوض

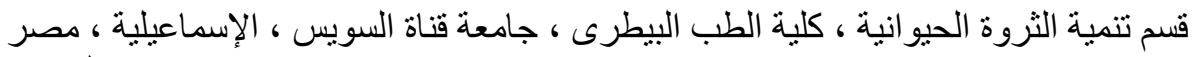

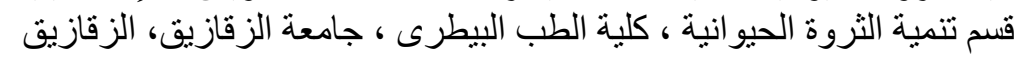

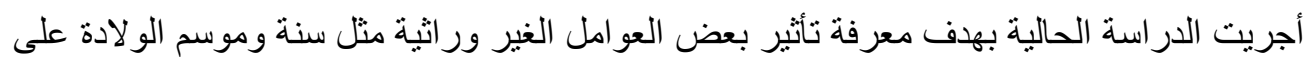

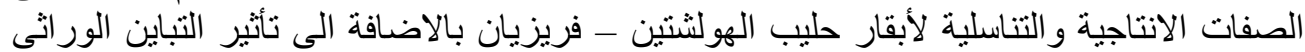

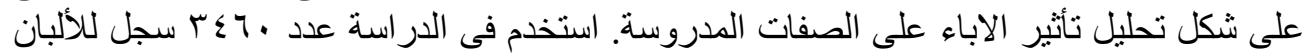

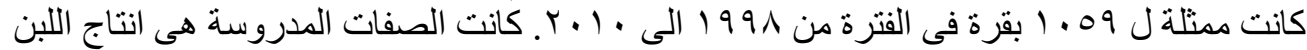

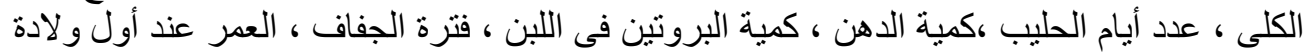

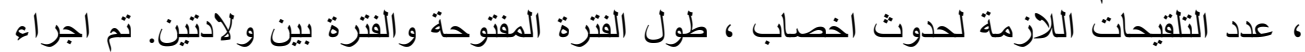

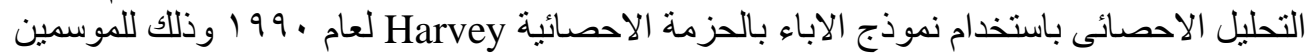

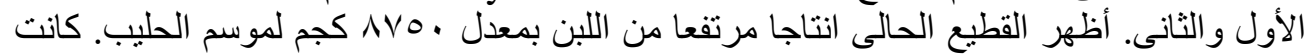

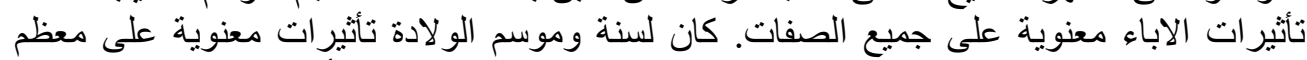

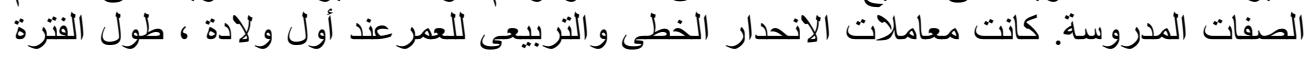

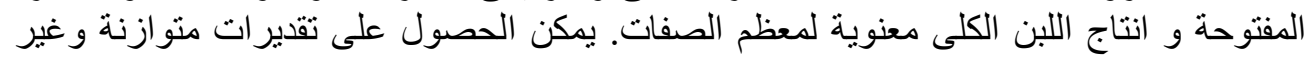

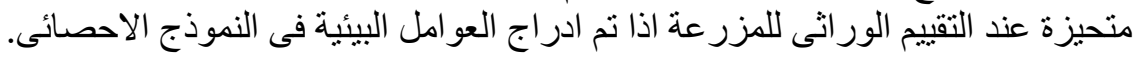

